\title{
Macrophage Inflammatory Protein 1 Beta Measurement
}

National Cancer Institute

\section{Source}

National Cancer Institute. Macrophage Inflammatory Protein 1 Beta Measurement. NCI Thesaurus. Code C82024.

The determination of the amount of macrophage inflammatory protein 1 beta present in a sample. 